\title{
Altered profile of mRNA expression in atrioventricular node of streptozotocin-induced diabetic rats
}

\author{
FRANK CHRISTOPHER HOWARTH ${ }^{1}$, KHATIJA PAREKH ${ }^{1}$, PETRILLA JAYAPRAKASH ${ }^{1}$, \\ EDWARD SAMUEL INBARAJ ${ }^{1}$, MURAT OZ ${ }^{2}$, HALINA DOBRZYNSKI ${ }^{3}$ and THOMAS EDWARD ADRIAN ${ }^{1}$
}

\author{
Departments of ${ }^{1}$ Physiology and ${ }^{2}$ Pharmacology, College of Medicine and Health Sciences, UAE University, Al Ain 17666, \\ United Arab Emirates; ${ }^{3}$ Institute of Cardiovascular Sciences, University of Manchester, Manchester M13 9NT, United Kingdom
}

Received March 7, 2017; Accepted July 11, 2017

DOI: $10.3892 / \mathrm{mmr} .2017 .7038$

\begin{abstract}
Prolonged action potential duration, reduced action potential firing rate, upstroke velocity and rate of diastolic depolarization have been demonstrated in atrioventricular node (AVN) cells from streptozotocin (STZ)-induced diabetic rats. To further clarify the molecular basis of these electrical disturbances, the mRNA profiles encoding a variety of proteins associated with the generation and conduction of electrical activity in the AVN, were evaluated in the STZ-induced diabetic rat heart. Expression of mRNA was measured in AVN biopsies using reverse transcription-quantitative polymerase chain reaction techniques. Notable differences in mRNA expression included upregulation of genes encoding membrane and intracellular $\mathrm{Ca}^{2+}$ transport, including solute carrier family 8 member $\mathrm{A} 1$, transient receptor potential channel 1 , ryanodine receptor $2 / 3$, hyperpolarization-activated cyclic-nucleotide 2 and 3, calcium channel voltage-dependent, $\beta 2$ subunit and sodium channels $3 \mathrm{a}, 4 \mathrm{a}, 7 \mathrm{a}$ and $3 \mathrm{~b}$. In addition to this, potassium channels potassium voltage-gated channel subfamily A member 4, potassium channel calcium activated intermediate/small conductance subfamily $\mathrm{N} \alpha$ member 2 , potassium voltage-gated channel subfamily $\mathrm{J}$ members 3,5 , and 11 , potassium channel subfamily $\mathrm{K}$ members $1,2,3$ and natriuretic peptide $\mathrm{B}$ (BNP) were upregulated in AVN of STZ heart, compared with controls. Alterations in gene expression were associated with upregulation of various proteins including the inwardly rectifying, potassium channel $\mathrm{K}_{\mathrm{ir}} 3.4$, NCX1 and BNP. The present study demonstrated notable differences in the profile of mRNA encoding proteins associated with the generation, conduction and regulation of electrical signals in the AVN of the STZ-induced diabetic rat heart. These data will provide a basis for a substantial range of future studies to
\end{abstract}

Correspondence to: Professor Frank Christopher Howarth, Department of Physiology, College of Medicine and Health Sciences, UAE University, Tawam Street, Al Ain 17666, United Arab Emirates E-mail: chris.howarth@uaeu.ac.ae

Key words: mRNA, heart, atrioventricular node, diabetes mellitus, Streptozotocin-induced diabetic rat investigate whether variations in mRNA translate into alterations in electrophysiological function.

\section{Introduction}

Diabetes mellitus (DM) is a serious global health problem and there is clear evidence of the negative influence of diabetes on the prevalence, severity, and prognosis of cardiovascular disease (1). Disorders of the vasculature, particularly coronary artery disease and hypertension, increase the incidence of mortality in individuals with DM (2). Diabetic patients are at greater risk of developing heart problems that are independent of vascular dysfunction which is indicative of a distinct diabetic cardiomyopathy $(3,4)$. Impaired contractile function including a reduction in amplitude and depressed time course of contraction and relaxation of ventricular myocytes have been demonstrated in experimental models of DM including the streptozotocin (STZ)-induced diabetic rat (5-10). These changes in contractility have been partly attributed to alterations in $\mathrm{Ca}^{2+}$ transport including elevated diastolic $\mathrm{Ca}^{2+}$ and depression in amplitude and prolonged time course of the intracellular $\mathrm{Ca}^{2+}$ transient $(6-8,11,12)$. Mechanisms underlying the alterations in $\mathrm{Ca}^{2+}$ transient include impaired sarcoplasmic reticulum (SR) $\mathrm{Ca}^{2+}$ transport and suppressed L-type $\mathrm{Ca}^{2+}$ current and $\mathrm{Na}^{+} / \mathrm{Ca}^{2+}$ exchange current (5-7,11-15). DM also has profound effects on the electrical conduction system of the heart which may give rise to arhythmogenic activity. Prolongation of the QT interval and QRS complex correlate with an increased incidence of sudden cardiac death in diabetic patients $(16,17)$. Atrial fibrillation is prevalent and there is a higher incidence of atrioventricular block in diabetic patients compared to healthy controls (17-20).

Previous in vivo biotelemetry and isolated perfused heart studies have demonstrated reduced heart rate in the STZ rat (21-23). Slowing of electrical conduction has also been demonstrated in diabetic rat myocardium (24). Various experimental studies in animal models of DM have variously demonstrated changes in ion channel activity including depressed L-type calcium current, transient outward potassium current, rapid and slow delayed potassium rectifier currents all of which can result in a prolongation of action potential duration and reduced heart rate (23,25-33). DM can increase the duration of the sinoatrial node (SAN) action potential and 
prolong sino-atrial node conduction time and pacemaker cycle length which is associated with alterations in intercellular gap junctional coupling $(23,34)$. Previous studies in STZ rat have demonstrated a variety of changes in mRNA, and in some cases proteins, that are important to the generation of action potentials in the SAN (35). Increased duration of the action potential in STZ-induced diabetic rat AVN has been attributed to a leftward shift in the zero current potential under voltage clamp, a reduction in peak L-type $\mathrm{Ca}^{2+}$ current density and reduced amplitude of delayed rectifier and hyperpolarization-activated currents (32). L-type calcium channels are fundamental to normal activity in the atrioventricular node (AVN) region and L-type calcium current contributes to the late stages of the pacemaker potential and generation of the action potential upstroke, and is responsible for the timing of conduction velocity through the AVN, thereby contributing to PR interval duration.

Previous studies have demonstrated increased action potential duration associated with a reduced action potential firing rate that is associated with reductions in L-type calcium current, delayed rectifier and hyperpolarization-activated currents in AVN cells from STZ-induced diabetic rat $(32,33)$. Modification of ion channel properties either by altered trafficking and expression, or post-translational modification of channel gating properties, can therefore have a significant impact on AVN function, and result in clinical AVN abnormalities. To further clarify the molecular basis of electrical disturbances in the AVN of diabetic heart the profile of mRNA that encodes a wide variety of proteins that are associated with the generation and conduction of electrical activity in the AVN has been evaluated in the STZ-induced diabetic rat heart.

\section{Materials and methods}

Experimental protocol. Forty male Wistar rats aged 8 weeks were divided into 2 subgroups. All animals received normal rat chow and drinking water ad libitum. One subgroup of rats received STZ/citrate buffer $(60 \mathrm{mg} / \mathrm{kg}$, intraperitoneal) whilst the other subgroup received citrate buffer alone. Blood glucose was measured 5 days following STZ treatment to confirm diabetes. Experiments began 12 weeks after STZ treatment. Body weight, heart weight and blood glucose were measured immediately prior to experiments. Approval for this study was obtained from the Animal Ethics Committee, College of Medicine and Health Sciences, United Arab Emirates University.

Expression of $m R N A$. Expression of genes encoding a wide range of cardiac proteins was assessed using previously described techniques with small modifications (35). After animals were sacrificed the hearts were removed rapidly and placed in a dish containing: $\mathrm{NaCl} 140 \mathrm{mM} ; \mathrm{KCl} 5.4 \mathrm{mM} ; \mathrm{MgCl}_{2}$ $1 \mathrm{mM}$; HEPES $5 \mathrm{mM}$; D-glucose $5.5 \mathrm{mM} ; \mathrm{CaCl}_{2} 1.8 \mathrm{mM}$ and adjusted to $\mathrm{pH} 7.4$ with $\mathrm{NaOH}$. Hearts were dissected and $2 \mathrm{~mm}$ biopsy samples of AVN were carefully collected from 20 STZ and 20 control hearts as illustrated in Fig. 1 and according to previously described techniques (36-38). Immediately after removal AVN samples were immersed in RNAlater (AM7021; Life Technologies, Carlsbad, CA, USA) and stored overnight at room temperature to allow thorough penetration of the tissue. AVN samples were then frozen at $-20^{\circ} \mathrm{C}$ pending further processing. Samples were homogenized at $6,500 \mathrm{rpm}$ for

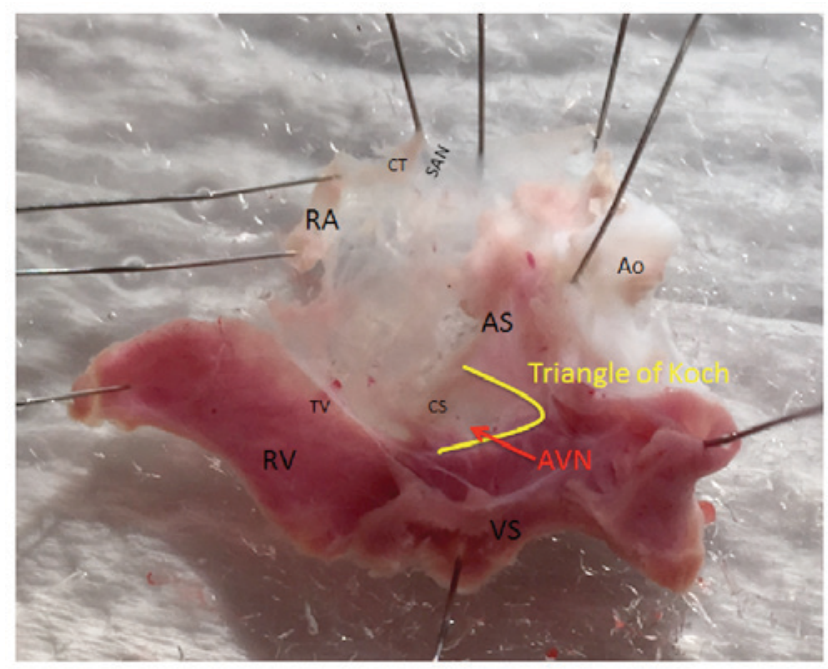

Figure 1. Dissection of the atrioventricular node junction in a typical control heart showing the location where tissue samples were collected. CT, crista terminalis; RA, right atrium; TV, tricuspid valve; RV, right ventricle; VS ventricular septum; AS, atrial septum; CS, coronary sinus; SAN, sinoatrial node; AVN, atrioventricular node; Ao, Aorta.

2 runs of $20 \mathrm{sec}$ each with a $15 \mathrm{sec}$ gap (Preceylls 24; Bertin Technologies, Raleigh, NC, USA). The SV Total RNA Isolation system (Promega, Madison, WI, USA) was used to isolate total RNA. The concentration and purity of the RNA was determined by measuring the ratio of absorbance at $260 \mathrm{~nm}$ and $280 \mathrm{~nm}$ (ND-1000; NanoDrop). A two-step RT-PCR procedure was used to generate cDNA. Total RNA (500 ng) was converted into cDNA in a $25 \mu \mathrm{l}$ PCR reaction with 10x RT Buffer $2.0 \mu \mathrm{l}$, 25x dNTP Mix (100 mM) $0.8 \mu 1$, 10x RT Random Primers $2.0 \mu 1$, MultiScribe ${ }^{\mathrm{TM}}$ Reverse Transcriptase $1.0 \mu \mathrm{l}$, RNase inhibitor $1.0 \mu \mathrm{l}$, and nuclease-free $\mathrm{H}_{2} \mathrm{O}$ (High Capacity cDNA Reverse Transcription kit (4374966; Applied Biosystems, Foster, CA, USA). Reverse transcription was carried out using the following protocol: $25^{\circ} \mathrm{C}$ for $10 \mathrm{~min}, 37^{\circ} \mathrm{C}$ for $120 \mathrm{~min}$, and $85^{\circ} \mathrm{C}$ for $5 \mathrm{~min}$ on the Veriti thermal cycler (Applied Biosystems). Gene Expression Assays were performed using custom TaqMan Low Density Arrays (Format 32, 4346799; Applied Biosystems). The TaqMan assays are pre-loaded in each reaction well of the array in triplicate for each RNA sample. As in previous experiments in heart 18S RNA was used as an endogenous control $(39,40)$. Expression of $18 \mathrm{~S}$ was not significantly different $(\mathrm{P}>0.05)$ between AVN samples collected from STZ and control hearts. cDNA (RNA-equivalent) (100 ng) was loaded together with 2x TaqMan Gene Expression Master Mix (No AmpErase UNG; Applied Biosystems) for a total of $100 \mu \mathrm{l}$ per port. Two AVN samples were combined for each real-time RT-PCR assay. Real-time RT-PCR was performed in a Fast ABI Prism 7900HT Sequence Detection system (Applied Biosystems). The PCR thermal cycling parameters were run in standard mode as follows: $50^{\circ} \mathrm{C}$ for $2 \mathrm{~min}, 94.5^{\circ} \mathrm{C}$ for $10 \mathrm{~min}$, followed by 40 cycles of $97^{\circ} \mathrm{C}$ for $30 \mathrm{sec}$ and $59.7^{\circ} \mathrm{C}$ for $1 \mathrm{~min}$. Results were initially analyzed using ABI Prism 7900HT SDS, v2.4. Calculations and statistical analysis were performed by the SDS RQ Manager 1.1.4 software using the $2^{-\Delta \Delta C t}$ method with a relative quantification $R Q \min / \mathrm{RQmax}$ confidence set at $95 \%$. A list of the target genes, proteins and protein descriptions are shown in Table I. 
Table I. Target genes and proteins.

\begin{tabular}{|c|c|c|}
\hline Genes & Proteins & Protein descriptions \\
\hline \multicolumn{3}{|c|}{ Intercellular proteins } \\
\hline Gjal & $\mathrm{Cx} 43$ & Connexin43 \\
\hline Gja5 & $\mathrm{Cx} 40$ & Connexin40 \\
\hline Gjcl & $\mathrm{Cx} 45$ & Connexin45 \\
\hline Gjd3 & Cx31.9 & Connexin31.9 \\
\hline \multicolumn{3}{|c|}{ Cell membrane transport } \\
\hline Atplal & $\mathrm{Na} / \mathrm{K}$ ATPase, $\alpha 1$ & ATPase, $\mathrm{Na}^{+} / \mathrm{K}^{+}$transporting, $\alpha 1$ polypeptide \\
\hline Atpla2 & $\mathrm{Na} / \mathrm{K}$ ATPase, $\alpha 2$ & ATPase, $\mathrm{Na}^{+} / \mathrm{K}^{+}$transporting, $\alpha 2$ polypeptide \\
\hline Atpla3 & $\mathrm{Na} / \mathrm{K}$ ATPase, $\alpha 3$ & ATPase, $\mathrm{Na}^{+} / \mathrm{K}^{+}$transporting, $\alpha 3$ polypeptide \\
\hline Atplb1 & $\mathrm{Na} / \mathrm{K}$ ATPase, $\beta 1$ & ATPase, $\mathrm{Na}^{+} / \mathrm{K}^{+}$transporting, $\beta 1$ polypeptide \\
\hline Atp2bl & $\mathrm{Na} / \mathrm{K}$ ATPase, $\beta 2$ & ATPase, $\mathrm{Ca}^{++}$transporting, plasma membrane 1 \\
\hline Slc8al & NCX1 & Solute carrier family 8 (sodium/calcium exchanger), member 1 \\
\hline Trpcl & TRPC1 & Transient receptor potential channel 1 \\
\hline $\operatorname{Trpc} 3$ & TRPC3 & Transient receptor potential channel 3 \\
\hline $\operatorname{Trpc} 4$ & TRPC4 & Transient receptor potential channel 4 \\
\hline Trpc6 & TRPC6 & Transient receptor potential channel 6 \\
\hline
\end{tabular}

Intracellular $\mathrm{Ca}^{2+}$ transport and $\mathrm{Ca}^{2+}$ regulation

$\begin{array}{ll}\text { Atp2a2 } & \text { SERCA } \\ \text { Calm1 } & \text { Calm1 } \\ \text { Calm3 } & \text { Calm3 } \\ \text { Casq2 } & \text { Casq2 } \\ \text { Itpr1 } & \text { IP3R1 } \\ \text { Itpr2 } & \text { IP3R2 } \\ \text { Itpr3 } & \text { IP3R3 } \\ \text { Ryr2 } & \text { RYR2 } \\ \text { Ryr3 } & \text { RYR3 } \\ \text { Pln } & \text { PLB }\end{array}$

Hyperpolarization-activated cyclic nucleotide-gated channels

$\begin{array}{ll}\text { Hcn1 } & \text { HCN1 } \\ \text { Hcn2 } & \text { HCN2 } \\ \text { Hcn3 } & \text { HCN3 } \\ \text { Hcn4 } & \text { HCN4 }\end{array}$

Calcium channels

$\begin{array}{ll}\text { Cacnalc } & \mathrm{Ca}_{\mathrm{v}} 1.2 \\ \text { Cacnald } & \mathrm{Ca}_{\mathrm{v}} 1.3 \\ \text { Cacnalg } & \mathrm{Ca}_{\mathrm{v}} 3.1 \\ \text { Cacnalh } & \mathrm{Ca}_{\mathrm{v}} 3.2 \\ \text { Cacna2d1 } & \mathrm{Ca}_{\mathrm{v}} \alpha 2 \delta 1 \\ \text { Cacna2d2 } 2 \delta & \mathrm{Ca}_{\mathrm{v}} \alpha 2 \delta 2 \\ \text { Cacna2d3 } & \mathrm{Ca}_{\mathrm{v}} \alpha 2 \delta 3 \\ \text { Cacnb1 } & \mathrm{Ca}_{\mathrm{v}} \beta 1 \\ \text { Cacnb2 } & \mathrm{Ca}_{\mathrm{v}} \beta 2 \\ \text { Cacnb3 } & \mathrm{Ca}_{\mathrm{v}} \beta 3 \\ \text { Cacng4 } & \mathrm{Ca}_{\mathrm{v}} \gamma 4 \\ \text { Cacng7 } & \mathrm{Ca}_{\mathrm{v}} \gamma 7\end{array}$

Sodium channels

$\begin{array}{ll}\text { Scnla } & \mathrm{Na}_{\mathrm{v}} 1.1 \\ \text { Scn3a } & \mathrm{Na}_{\mathrm{v}} 1.3 \\ \text { Scn } 4 a & \mathrm{Na}_{\mathrm{v}} 1.4\end{array}$

Sarcoplasmic/endoplasmic reticulum calcium ATPase 2

Calmodulin 1

Calmodulin3

Calsequestrin 2

Inositol 1,4,5-trisphosphate receptor, type 1

Inositol 1,4,5-trisphosphate receptor, type 2

Inositol 1,4,5-trisphosphate receptor, type 3

Ryanodine receptor 2

Ryanodine receptor 3

Phospholamban

Hyperpolarization-activated cyclic nucleotide-gated channels 1 Hyperpolarization-activated cyclic nucleotide-gated channels 2 Hyperpolarization-activated cyclic nucleotide-gated channels 3 Hyperpolarization-activated cyclic nucleotide-gated channels 4

Voltage-dependent, L type, $\alpha 1 \mathrm{C}$ subunit

Voltage-dependent, L type, $\alpha 1 \mathrm{D}$ subunit

Voltage-dependent, $\mathrm{T}$ type, $\alpha 1 \mathrm{G}$ subunit

Voltage-dependent, $\mathrm{T}$ type, $\alpha 1 \mathrm{H}$ subunit

Voltage-dependent, $\alpha 2 / \delta$ subunit 1

Voltage-dependent, $\alpha 2 / \delta$ subunit 2

Voltage-dependent, $\alpha 2 / \delta$ subunit 3

Voltage-dependent, $\beta 1$ subunit

Voltage-dependent, $\beta 2$ subunit

Voltage-dependent, $\beta 3$ subunit

Voltage-dependent, $\gamma$ subunit 4

Voltage-dependent, $\gamma$ subunit 7

Voltage gated, type I $\alpha$ subunit

Voltage gated, type III $\alpha$ subunit

Voltage gated, type IV $\alpha$ subunit 
Table I. Continued.

\begin{tabular}{|c|c|c|}
\hline Genes & Proteins & Protein descriptions \\
\hline $\operatorname{Scn} 5 a$ & $\mathrm{Na}_{\mathrm{v}} 1.5$ & Voltage gated, type $\mathrm{V}, \alpha$ subunit \\
\hline Scn $7 a$ & $\mathrm{Na}_{\mathrm{v}} 2.1$ & Voltage gated, type VII, $\alpha$ subunit \\
\hline Scn8a & $\mathrm{Na}_{\mathrm{v}} 1.6$ & Voltage gated, type VIII, $\alpha$ subunit \\
\hline Scn $1 b$ & $\mathrm{Na}_{\mathrm{v}} \beta 1$ & Voltage gated, type I, $\beta$ subunit \\
\hline $\operatorname{Scn} 2 b$ & $\mathrm{Na}_{\mathrm{v}} \beta 2$ & Voltage gated, type II, $\beta$ subunit \\
\hline Scn3b & $\mathrm{Na}_{\mathrm{v}} \beta 3$ & Voltage gated, type III, $\beta$ subunit \\
\hline \multicolumn{3}{|c|}{ Potassium channels } \\
\hline Kcnal & $\mathrm{K}_{\mathrm{v}} 1.1$ & Voltage gated shaker related subfamily A, member 1 \\
\hline Kcna2 & $\mathrm{K}_{\mathrm{v}} 1.2$ & Voltage gated shaker related subfamily A, member 2 \\
\hline Kcna3 & $\mathrm{K}_{\mathrm{v}} 1.3$ & Voltage gated shaker related subfamily A, member 3 \\
\hline Kcna4 & $\mathrm{K}_{\mathrm{v}} 1.4$ & Voltage gated shaker related subfamily A, member 4 \\
\hline Kcna5 & $\mathrm{K}_{\mathrm{v}} 1.5$ & Voltage gated shaker related subfamily A, member 5 \\
\hline Kcna6 & $\mathrm{K}_{\mathrm{v}} 1.6$ & Voltage gated shaker related subfamily A, member 6 \\
\hline Kcnbl & $\mathrm{K}_{\mathrm{v}} 2.1$ & Voltage gated shab related subfamily B, member 1 \\
\hline Kcnd1 & $\mathrm{K}_{\mathrm{v}} 4.1$ & Voltage gated shal related subfamily D, member 1 \\
\hline Kcnd2 & $\mathrm{K}_{\mathrm{v}} 4.2$ & Voltage gated shal related subfamily D, member 2 \\
\hline Kcnd3 & $\mathrm{K}_{\mathrm{v}} 4.3$ & Voltage gated shal related subfamily D, member 3 \\
\hline Kcnh2 & ERG-1 & Ether-a-go-go-related protein 1 \\
\hline Kcnip2 & KChIP2 & Kv channel interacting protein 2 \\
\hline Kcnnl & SK1 & $\begin{array}{l}\mathrm{Ca}^{++} \text {activated intermediate/small conductance subfamily } \mathrm{n} \\
\alpha, \text { member } 1\end{array}$ \\
\hline Kcnn2 & SK2 & $\begin{array}{l}\mathrm{Ca}^{++} \text {activated intermediate/small conductance subfamily } \mathrm{n} \\
\alpha, \text { member } 2\end{array}$ \\
\hline Kcnn3 & SK3 & $\begin{array}{l}\mathrm{Ca}^{++} \text {activated intermediate/small conductance subfamily } \mathrm{n} \\
\alpha, \text { member } 3\end{array}$ \\
\hline Kcnql & $\mathrm{K}_{\mathrm{v}} 7.1$ & Voltage gated KQT-like subfamily Q, member 1 \\
\hline Kcnj2 & $\mathrm{K}_{\mathrm{ir}} 2.1$ & Inwardly rectifying subfamily $\mathrm{J}$, member 2 \\
\hline Kcnj3 & $\mathrm{K}_{\mathrm{ir}} 3.1$ & Inwardly rectifying subfamily $\mathrm{J}$, member 3 \\
\hline Kcnj5 & $\mathrm{K}_{\mathrm{ir}} 3.4$ & Inwardly rectifying subfamily $\mathrm{J}$, member 5 \\
\hline Kcnj8 & $\mathrm{K}_{\mathrm{ir}} 6.1$ & Inwardly rectifying subfamily $\mathrm{J}$, member 8 \\
\hline Kcnj11 & $\mathrm{K}_{\mathrm{ir}} 6.2$ & Inwardly rectifying subfamily $\mathrm{J}$, member 11 \\
\hline Kcnj12 & $\mathrm{K}_{\mathrm{ir}} 2.2$ & Inwardly rectifying subfamily $\mathrm{J}$, member 12 \\
\hline Kcnj14 & $\mathrm{K}_{\mathrm{ir}} 2.4$ & Inwardly rectifying subfamily $\mathrm{J}$, member 14 \\
\hline Kcnk1 & TWIK1 & Two pore domain subfamily K, member 1 \\
\hline Kcnk2 & TREK1 & Two pore domain subfamily $\mathrm{K}$, member 2 \\
\hline Kcnk3 & $\mathrm{K}_{2 \mathrm{P}} 3.1$ & Two pore domain subfamily $\mathrm{K}$, member 3 \\
\hline Kcnk5 & $\mathrm{K}_{2 \mathrm{P}} 5.1$ & Two pore domain subfamily $\mathrm{K}$, member 5 \\
\hline Kcnk6 & TWIK2 & Two pore domain subfamily $\mathrm{K}$, member 6 \\
\hline \multicolumn{3}{|c|}{ Miscellaneous proteins } \\
\hline Abcc8 & SUR1 & ATP-binding cassette transporter sub-family $\mathrm{C}$ member 8 \\
\hline$A b c c 9$ & SUR2 & ATP-binding cassette, sub-family C member 9 \\
\hline Nppa & ANP & Atrial natriuretic peptide \\
\hline$N p p b$ & BNP & Brain natriuretic peptide \\
\hline Pias3 & KChAP & Protein inhibitor of activated STAT, 3 \\
\hline
\end{tabular}

Expression of protein. Protein expression was measured using previously described SDS-PAGE and western blotting techniques with small modifications (35). AVN from STZ and control rats were carefully dissected, rinsed with ice-cold saline and homogenised in RIPA buffer (Tris $50 \mathrm{mM}$; $\mathrm{NaCl} 150 \mathrm{mM}$; Triton X 1\%; sodium deoxylate $0.5 \%$;
SDS $0.1 \%$ adjusted to $\mathrm{pH} 7.4$ and finally addition of PMSF $0.1 \mathrm{mM}$-Sigma, P7626) at 6,500 rpm for 2 runs of $20 \mathrm{sec}$ each with a $15 \mathrm{sec}$ gap (Preceylls 24; Bertin Technologies). Protein concentration was measured with Bio-Rad reagent. The supernatant was used for SDS-PAGE and western blotting. Protein $(40 \mu \mathrm{g})$ was electrophoretically separated onto 8 
Table II. General characteristics of streptozotocin-induced diabetic rats.

\begin{tabular}{lrc}
\hline Characteristics & \multicolumn{1}{c}{ Control } & Streptozotocin \\
\hline Bodyweight $(\mathrm{g})$ & $401.56 \pm 9.68$ & $246.44 \pm 13.28^{\mathrm{a}}$ \\
Heart weight $(\mathrm{g})$ & $1.37 \pm 0.03$ & $1.08 \pm 0.04^{\mathrm{a}}$ \\
Heart weight $/$ & $3.42 \pm 0.06$ & $4.47 \pm 0.12^{\mathrm{a}}$ \\
bodyweight $(\mathrm{mg} / \mathrm{g})$ & & \\
Blood glucose $(\mathrm{mg} / \mathrm{dl})$ & $99.88 \pm 2.07$ & $514.69 \pm 18.86^{\mathrm{a}}$ \\
\hline
\end{tabular}

Data are presented as the mean \pm standard error of the mean, $n=16$ hearts, ${ }^{\mathrm{a}} \mathrm{P}<0.01$.

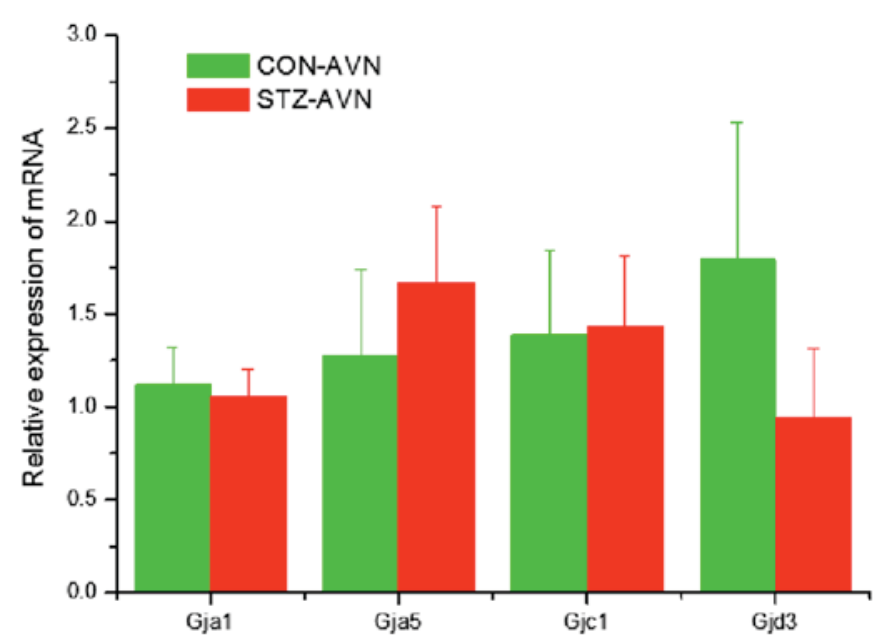

Figure 2. Expression of genes encoding various intercellular proteins. Data are mean \pm SEM, $n=6-8$ samples from STZ and control rat each containing samples from 2 hearts.

or $10 \%$ (depending on the molecular weight of the protein to be separated) polyacrylamide gels and transferred onto nitrocellulose membranes. Expression of the specific proteins was confirmed by immunoreaction with their specific antibodies by western blot analysis. $\beta$-actin was used as a loading control. Blots were developed using the Pierce Western Blot kit. Images were obtained using the Typhoon FLA 9500, GE Healthcare Bio-Sciences AB (Uppsala, Sweden). Quantitation of protein was performed using the method described in the following website: http://lukemiller.org/index.php/2010/11/analyzin g-gels-and-western-blots-with-image-j/.

For each lane the protein level was normalized to that of $\beta$-actin. The ratio of specific protein signal to that of the $\beta$-actin control was used to calculate fold-change.

Statistical analysis. Results were expressed as the mean \pm SEM. of 'n' observations. Statistical comparisons were performed using independent sample t-test (SPSS vs. 20). P $\leq 0.05$ was considered to indicate a statistically significant difference.

\section{Results}

General characteristics: Bodyweight and heart weight were reduced and heart weight/bodyweight ratio was increased in

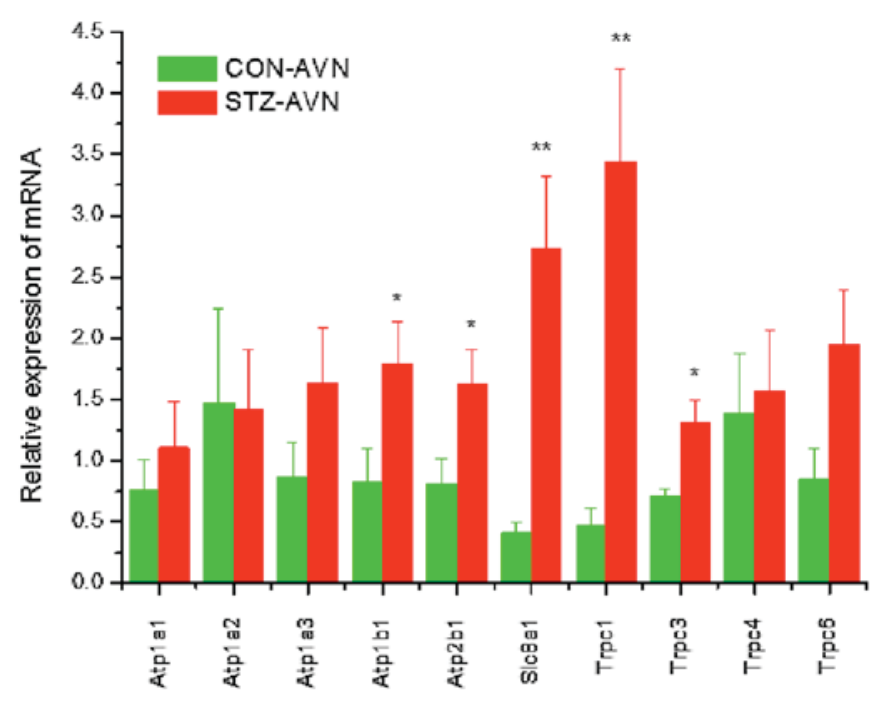

Figure 3. Expression of genes encoding various cell membrane transport proteins. Data are mean \pm SEM, $n=5-8$ samples from STZ and control rat each containing samples from 2 hearts. ${ }^{*} \mathrm{P}<0.05,{ }^{* *} \mathrm{P}<0.01$ vs. CON-AVN.

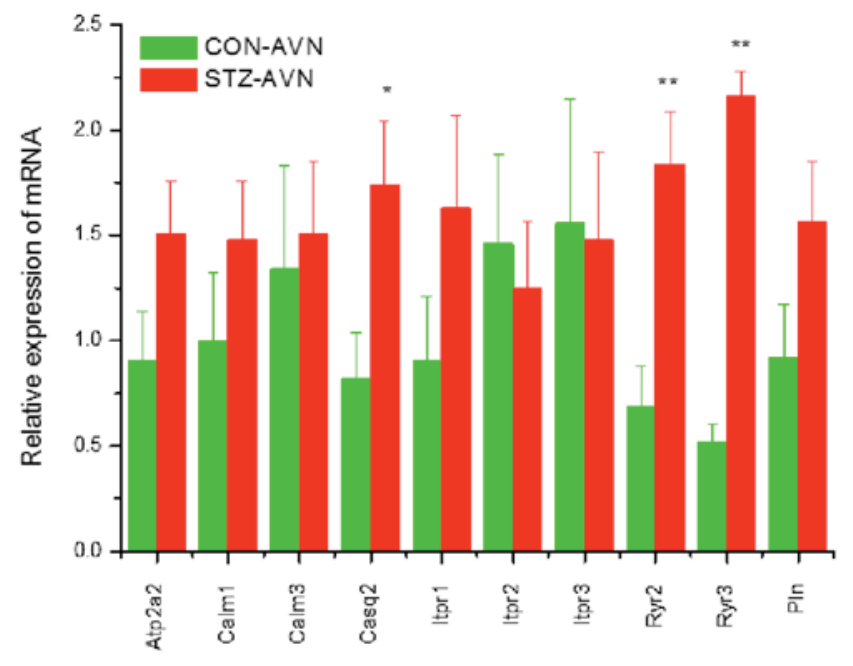

Figure 4. Expression of genes encoding various intracellular $\mathrm{Ca}^{2+}$ transport and $\mathrm{Ca}^{2+}$ regulation proteins. Data are mean \pm SEM, $\mathrm{n}=7-8$ samples from STZ and control rat each containing samples from 2 hearts. ${ }^{*} \mathrm{P}<0.05,{ }^{* * *} \mathrm{P}<0.01 \mathrm{vs}$. CON-AVN.

STZ rats compared to controls. Blood glucose was elevated 5 -fold in STZ rats compared to controls (Table II).

Expression of $m R N A$. Expression of genes encoding intercellular proteins is shown in Fig. 2. There were no significant ( $\mathrm{P}>0.05)$ differences in the expression of mRNA in AVN from STZ compared to control heart. Expression of genes encoding various cell membrane transport and intracellular $\mathrm{Ca}^{2+}$ transport and regulatory proteins are shown in Figs. 3 and 4, respectively. mRNA for Atplb1 (2-fold), Atp2b1 (2-fold), Slc8al (6-fold), Trpcl (7-fold), Trpc3 (2-fold), Casq2 (2-fold), Ryr2 (3-fold), Ryr3 (4-fold) were all significantly $(\mathrm{P}<0.05)$ upregulated in AVN from STZ compared to control heart. Expression of genes encoding the hyperpolarization-activated cyclic nucleotide-gated channel proteins are shown in Fig. 5. mRNA for Hcn2 (2-fold) and Hcn3 (9-fold) were significantly 


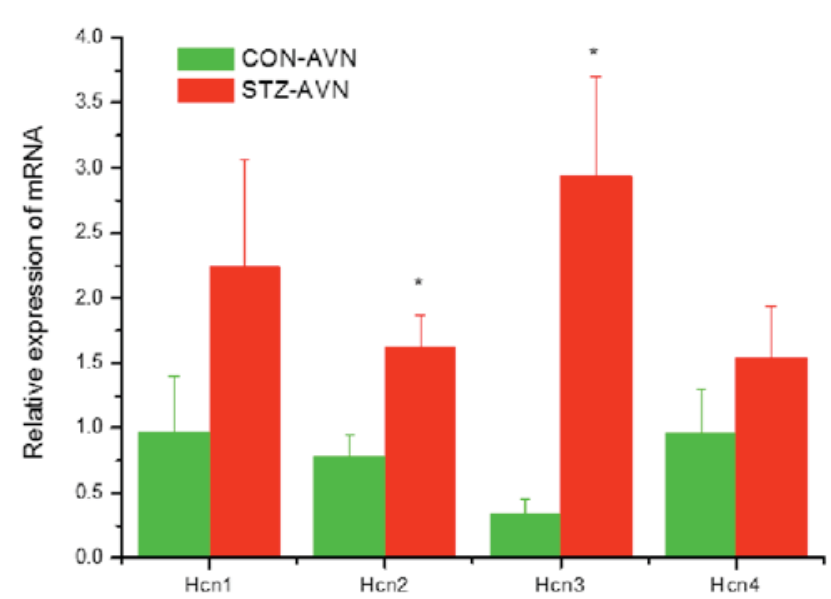

Figure 5. Expression of genes encoding various hyperpolarization-activated cyclic-nucleotide-gated channels. Data are mean \pm SEM, $n=5-8$ samples from STZ and control rat each containing samples from 2 hearts. "P<0.05 vs. CON-AVN.

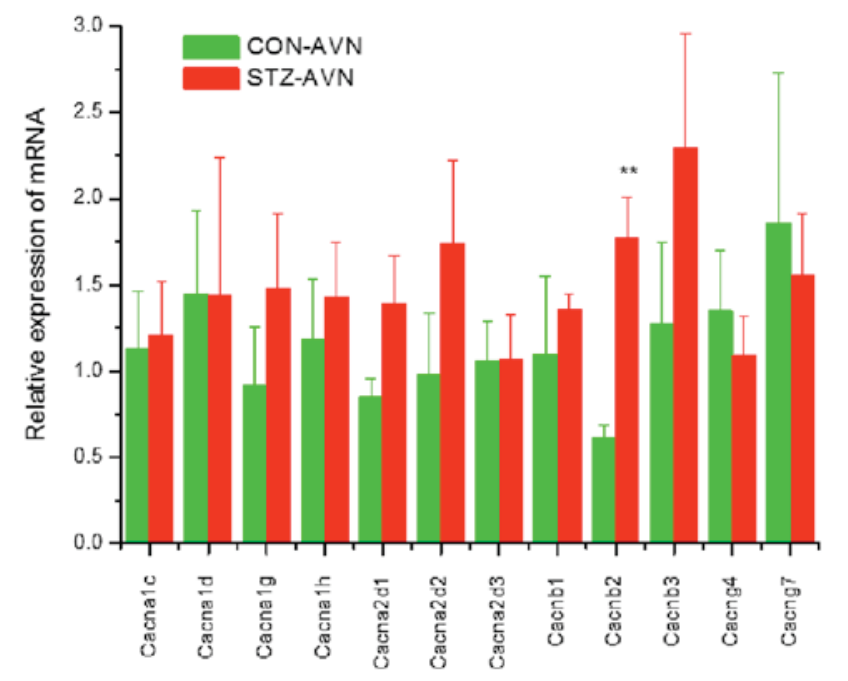

Figure 6. Expression of genes encoding various calcium channel proteins. Data are mean \pm SEM, $\mathrm{n}=5-9$ samples from STZ and control rat each containing samples from 2 hearts. ${ }^{* *} \mathrm{P}<0.01$ vs. CON-AVN.

upregulated in AVN from STZ compared to control heart. Expression of genes encoding calcium channel proteins are shown in Fig. 6. mRNA for Cacnb2 (2-fold) was upregulated in AVN from STZ compared to control heart. Expression of genes encoding sodium channel proteins are shown in Fig. 7. mRNA for Scn3a (3-fold), Scn4a (3-fold), Scn7a (2-fold) and $S c n 3 b$ (7-fold) were upregulated in AVN from STZ compared to control heart. Expression of genes encoding potassium channel proteins are shown in Fig. 8. mRNA for Kcna4 (3-fold), Kcnh2 (4-fold), Kcnn2 (9-fold), Kcnj3 (2-fold), Kcnj5 (5-fold), Kcnjl1 (2-fold), Kcnkl (2-fold), Kcnk2 (2-fold) and Kcnk3 (3-fold) were upregulated in AVN from STZ compared to control heart. Expression of genes encoding various miscellaneous proteins are shown in Fig. 9. mRNA for $A b c c 9$ (2-fold), Nppb (3-fold) and Pias3 (8-fold) were upregulated in AVN from STZ compared to Control heart.

Expression of proteins. Representative Western blots comparing various proteins from STZ and control AVN are

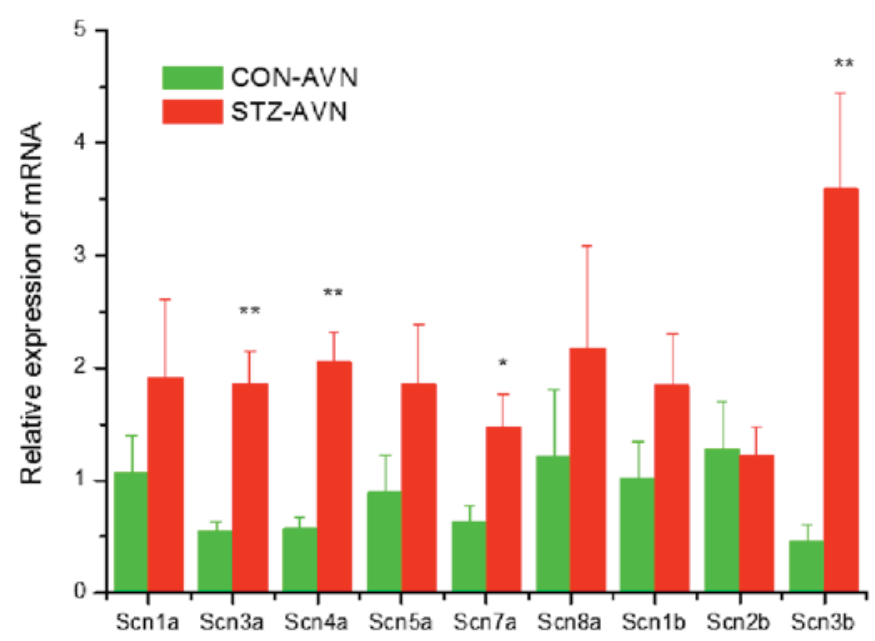

Figure 7. Expression of genes encoding various sodium channel proteins. Data are mean \pm SEM, $n=5-9$ samples from STZ and control rat each containing samples from 2 hearts. ${ }^{*} \mathrm{P}<0.05,{ }^{* *} \mathrm{P}<0.01$ vs. CON-AVN.
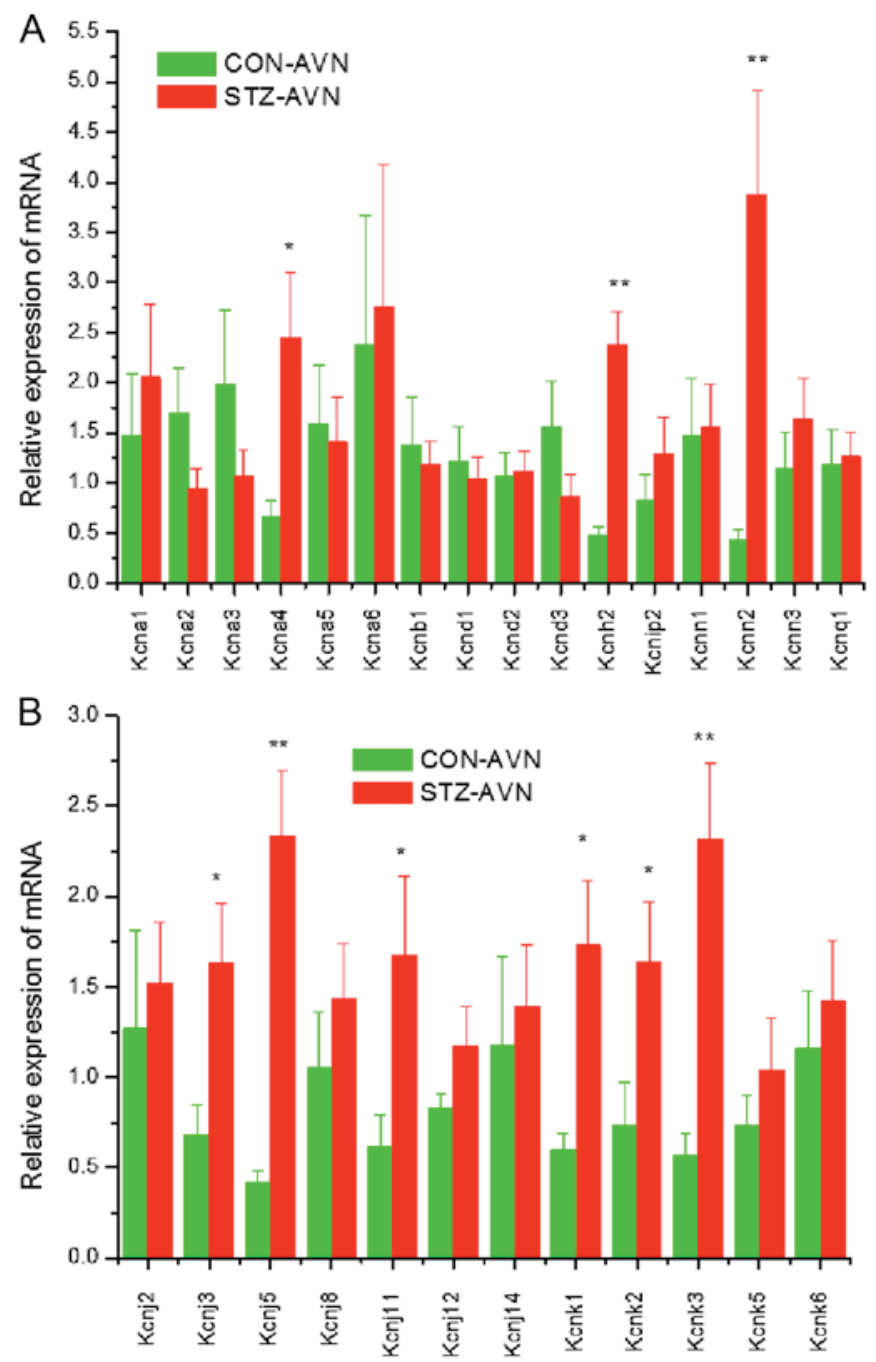

Figure 8. (A and B) Expression of genes encoding various potassium channel proteins. Data are mean \pm SEM, $n=5-8$ samples from STZ and control rat each containing samples from 2 hearts. ${ }^{*} \mathrm{P}<0.05,{ }^{* *} \mathrm{P}<0.01$ vs. CON-AVN.

shown in Fig. 10A. The protein/actin ratio for the different proteins are shown in Fig. 10B. Expression of $\mathrm{K}_{\mathrm{ir}} 3.4$, NCX1 


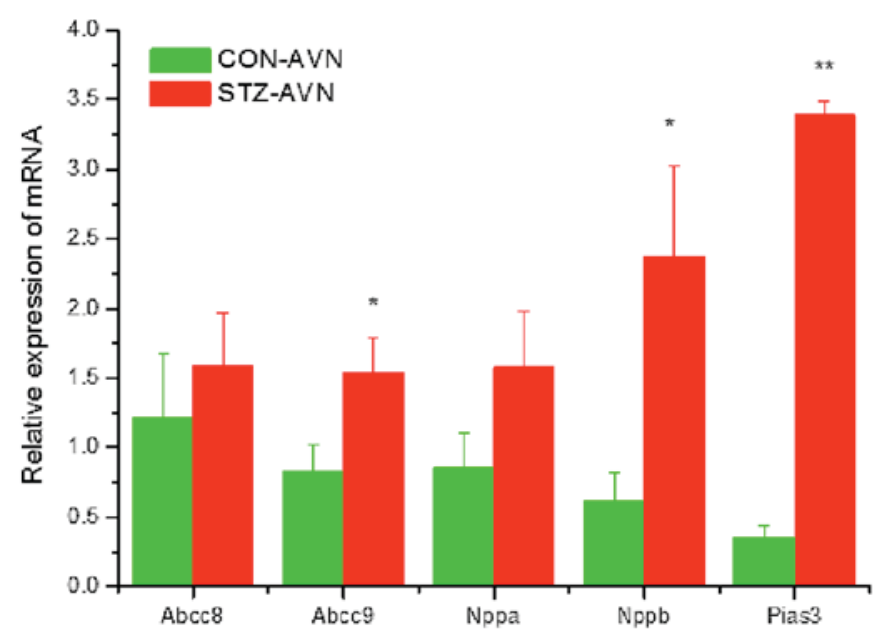

Figure 9. Expression of genes encoding miscellaneous cardiac proteins. Data are mean \pm SEM, $n=6-8$ samples from STZ and control rat each containing samples from 2 hearts. ${ }^{*} \mathrm{P}<0.05,{ }^{* *} \mathrm{P}<0.01$ vs. CON-AVN.

and BNP were significantly upregulated and SK2, ERG-1, $\mathrm{HCN} 3$ and $\mathrm{Na}_{\mathrm{v}} \beta 3$ were not significantly altered in AVN from STZ compared to control heart.

\section{Discussion}

Diabetes in the STZ-induced diabetic rat was characterized by reduced bodyweight and heart weight and increased heart weight/bodyweight ratio and a 5-fold increase in blood glucose. Major findings of this study included: i) upregulation of Slc $8 a 1$ mRNA and NCX1 protein; ii) upregulation of Trpc1 and Trpc3 mRNA; iii) upregulation of Ryr2 and Ryr3 mRNA; iv) upregulation of Hcn2 and Hcn3; v) upregulation of Cacnb2 mRNA; vi) upregulation of $S c n 3 a / 4 a / 7 a$ and $S c n 3 b$; vii) upregulation of Kcna4, Kcnh2, Kcnn2, Kcnj3/11 and Kcnk2/3 mRNA and Kcnj5 mRNA and $\mathrm{Ki}_{\mathrm{r}} 3.4$ protein; and viii) upregulation of $N p p b$ mRNA and BNP protein in AVN from STZ compared to control heart.

Slc8al mRNA and NCX1 protein were upregulated in AVN from STZ rat heart. Upregulation of Slc8al has also recently been reported in the SAN from STZ-induced diabetic rat (35). The Slc 8 gene family encodes the $\mathrm{Na}^{+} / \mathrm{Ca}^{2+}$ exchanger (NCX). Altered expression and regulation of $\mathrm{NCX}$ proteins contribute to abnormal $\mathrm{Ca}^{2+}$ homeostasis in heart failure, arrhythmia, hypertension and diabetes (41). Impaired $\mathrm{Ca}^{2+}$ homeostasis, due to depressed SR $\mathrm{Ca}^{2+}$ ATPase and NCX activity and NCX current have been demonstrated in ventricular myocytes from STZ-induced diabetic heart $(6,42,43)$. The functional importance of NCX current in rabbit and mouse AVN cells has been demonstrated and depressed L-type $\mathrm{Ca}^{2+}$ current has been reported in AVN cells from STZ rat heart (32,33,44-46). Upregulation of Slc8al mRNA and NCX1 protein in the AVN from STZ heart may provide a compensatory pathway to facilitate $\mathrm{Ca}^{2+}$ influx and/or $\mathrm{Ca}^{2+}$ efflux from the cell which may be required for the generation and recovery of action potentials in AVN cells.
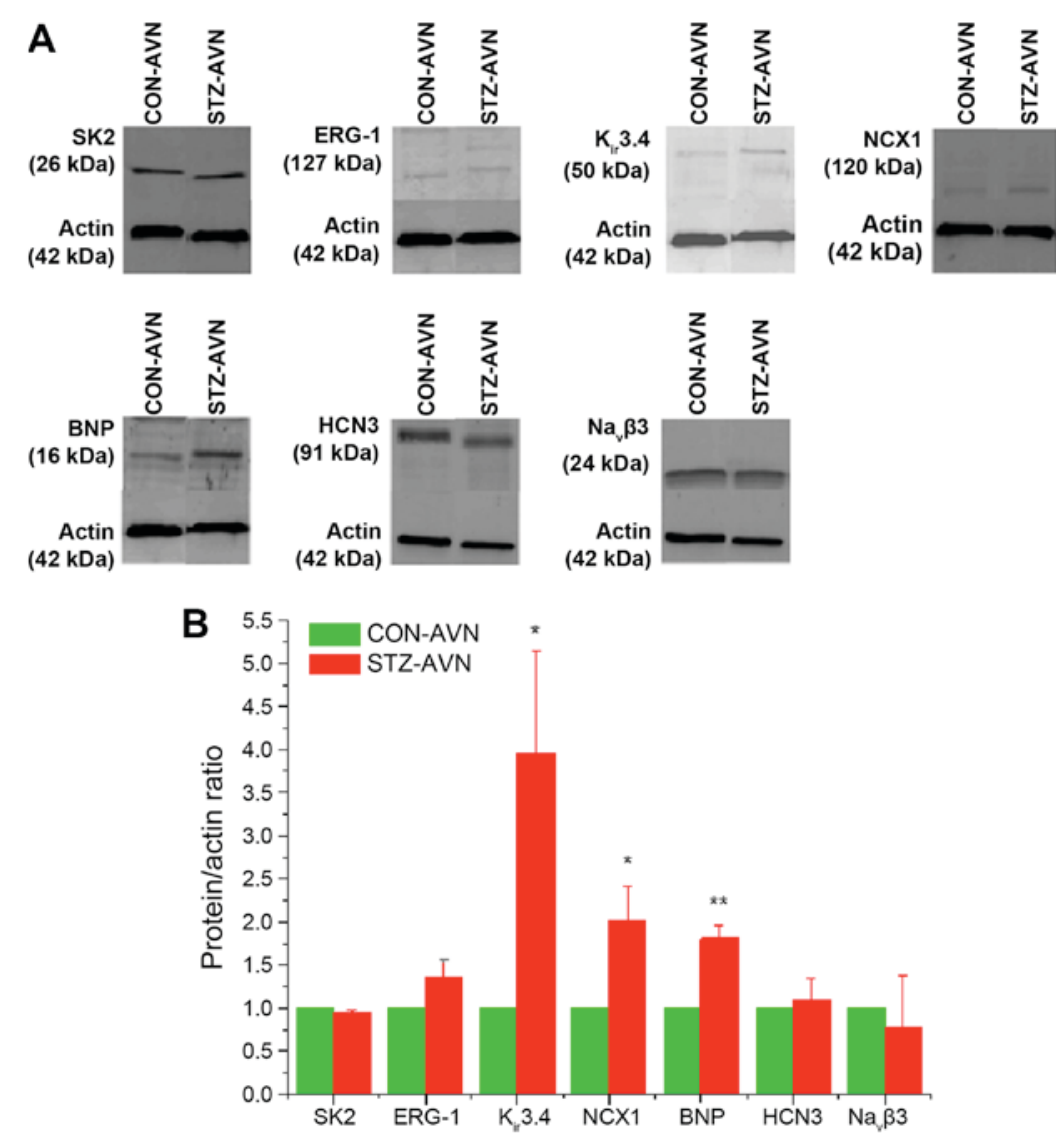

Figure 10. (A) Typical western blot comparing expression of various proteins from STZ and control AVN. $\beta$-actin which was used as the loading control is also shown in each blot. The blots shown are representative of 6 individual samples from STZ and control rats. (B) Protein/ $\beta$-actin ratios for the different proteins. Data are mean $\pm \mathrm{SEM}, \mathrm{n}=6$ samples from STZ and control rat each containing 3 pooled AVNs from a total of $18 \mathrm{hearts} \mathrm{AVN}$. ${ }^{*} \mathrm{P}<0.05,{ }^{* *} \mathrm{P}<0.01 \mathrm{vs}$. CON-AVN. 
Trpcl and Trpc3 were upregulated in AVN from STZ rat heart. Upregulation of Trpcl has also recently been reported in the SAN from STZ-induced diabetic rat (35). The transient receptor potential channels (TRPCs) are a large family of non-selective and non-voltage-gated ion channels that convey signaling information linked to a broad range of sensory inputs including neurohormonal and mechanical load stimulation (47). TRPC1 is a mechano-sensitive, non-selective cation channel which is expressed in ventricle and atrium in a variety of mammalian species including rat (48-50). TRPC1 functions in $\mathrm{Ca}^{2+}$ influx, and its upregulation is involved in the development of cardiac hypertrophy (51). TRPC1 is also expressed in mouse SAN and in single pacemaker cells and mouse SAN may exhibit store-operated $\mathrm{Ca}^{2+}$ channel (SOCC) activity which may suggest that SOCCs are involved in regulating pacemaker firing rate (52). Upregulation of Trpcl may be a consequence of hemodynamic disturbances in the diabetic heart which in turn stimulates mechano-sensitive TRPC channels thereby providing an alternative entry pathway for $\mathrm{Ca}^{2+}$ in the face of depressed L-type $\mathrm{Ca}^{2+}$ current in AVN cells and reduced heart rate in STZ-induced diabetic heart $(32,33)$. Previous studies have reported elevation of mean arterial pressure in STZ-induced diabetic rats which may in turn lead to hypertrophy of the heart which would be consistent with the increase in heart weight to body weight ratio, which in turn might elicit an effect on the mechano-sensitive channels (53).

Ryr2 and Ryr3 were upregulated in AVN from STZ rat heart. The $R y r$ family of genes encode proteins that form the $\mathrm{SR} \mathrm{Ca}^{2+}$ release channel. SR Ca ${ }^{2+}$ cycling is important for the genesis of spontaneous activity in the AVN (44,54-56). Whilst little is known about the effects of diabetes on $\mathrm{SR} \mathrm{Ca}^{2+}$ signaling in the AVN, previous studies have demonstrated depressed SR $\mathrm{Ca}^{2+}$ loading, $\mathrm{Ca}^{2+}$ uptake/release and $\mathrm{Ca}^{2+}$ leak in ventricular myocytes from STZ-induced diabetic heart $(6,12,15,57)$. These disturbances in $\mathrm{SR} \mathrm{Ca}^{2+}$ signaling have been variously attributed to structural and/or functional defects of the RYR2 receptors or $\mathrm{Ca}^{2+}$-ATPase (SERCA) pump proteins (12,15,58-61). It was also interesting to note upregulation of Casq2, an $\mathrm{SR} \mathrm{Ca}{ }^{2+}$ binding protein, in AVN from STZ rat. Upregulation of Ryr2 may facilitate release of $\mathrm{Ca}^{2+}$ from the $\mathrm{SR}$ which in turn might compensate for depressed L-type $\mathrm{Ca}^{2+}$ current in AVN from STZ compared to control heart $(32,33)$.

Hcn 2 and Hcn3 were upregulated in AVN from STZ rat heart. Upregulation of $\mathrm{Hcn} 3$ was only associated with a small increase in $\mathrm{HCN} 3$ protein in AVN from STZ compared to control heart. The funny current which is conducted through the hyperpolarization-activated cyclic nucleotide channels plays a key role in the generation of the pacemaker current and hence, rhythmicity of the heart. Previous studies have demonstrated reduced action potential firing rates accompanied by a reduction in the amplitude of funny current, L-type $\mathrm{Ca}^{2+}$ current and delayed rectifier current in AVN cells from STZ-induced diabetic heart $(32,33)$. In the longer term, as DM progresses, upregulation of Hcn2 and/or Hcn3, if accompanied by an increase in $\mathrm{HCN} 2$ and $\mathrm{HCN} 3$ protein, might result in an increase in the conductance of funny current and steepening of the slope of the pacemaker potential, which in turn would increase heart rate.

Cacnb2 was upregulated in AVN from STZ rat heart. Cacnb2 codes for the auxiliary $\beta$-subunit $(\operatorname{Cav} \beta)$ which is an important modulator of $\mathrm{Ca}^{2+}$ channel activity. Expression of the $\beta$-subunit is required for normal function of cardiac L-type $\mathrm{Ca}^{2+}$ channels. $\mathrm{Cav} \beta$ binds to the $\alpha 1$ pore-forming subunit of L-type $\mathrm{Ca}^{2+}$ channels and augments L-type $\mathrm{Ca}^{2+}$ current by facilitating channel opening and increasing the number of channels in the membrane (62). Several cardiovascular diseases including hypertension, heart failure and sudden cardiac death have been linked to Cacnb2 (63). Upregulation of Cacnb2 may facilitate L-type $\mathrm{Ca}^{2+}$ channel opening and provide a compensatory pathway for depressed L-type $\mathrm{Ca}^{2+}$ current in AVN cells from STZ compared to control heart $(32,33)$. Interestingly, there were no significant changes in the expression of Cacnalc and Cacnald suggesting that at this stage of diabetes (12 weeks after STZ treatment), whilst other changes in gene expression are taking place, changes to the $\alpha-1 \mathrm{C}$ and $\alpha-1 \mathrm{D}$ are not yet evident.

$S c n 3 b$ and $S c n 4 a$ were upregulated in AVN from STZ rat heart. Sodium channel SCN5a (Nav1.5) is regulated by four sodium channel auxiliary $\beta$ subunits (SCN1-4b). Mutations in SCN3b have been associated with ventricular and atrial arrhythmias and altered electrophysiological properties of the sodium channel including reduced peak sodium current (64-66). Sodium channel SCN4A (Nav1.4) encodes the $\alpha$-subunit of the voltage-gated sodium channel Nav1.4 and studies suggest the involvement of SCN4A variants in the pathophysiological mechanisms underlying arrhythmias in some patients with Brugada syndrome $(67,68)$. The role of $\mathrm{SCN} 3 \mathrm{~B}$ and SCN4A in AVN remains to be clarified.

Kcna4, Kcnh2, Kcnj3/5/11, Kcnk2/3 and Kcnn2 were all upregulated in AVN from STZ rat heart. Upregulation of $K c n j 5$ and Kcnk3 have also recently been reported in the SAN from STZ-induced diabetic rat (35). $\mathrm{K}_{\mathrm{ir}} 3.4$ protein encoded by Kcnj5 was upregulated and ERG-1 encoded by Kcnh 2 was unaltered in AVN from STZ compared to control heart. At this stage of diabetes (12 weeks after STZ treatment) alterations in gene expression might not translate into alterations in protein expression. Kcna 4 encodes the Kv1.4 protein which forms the channel that carries transient outward current which makes a major contribution to the repolarizing current and termination of the cardiac action potential. Transient outward current has been widely demonstrated in different regions of the heart including ventricular myocytes and AVN cells (69-71). Kcnh2 encodes ERG-1 protein which is the $\alpha$ subunit of a potassium ion channel that mediates the repolarizing rapid delayed rectifier current $\left(\mathrm{I}_{\mathrm{Kr}}\right)$ current in the cardiac action potential. Several studies have characterized the electrophysiological properties of $\mathrm{I}_{\mathrm{Kr}}$ in AVN cells from various species including rabbit and mouse $(54,71-73)$. $\mathrm{I}_{\mathrm{Kr}}$ plays a role in both action potential repolarization and pacemaker depolarization $(74,75)$. The Kcnj5 gene encodes the G-protein-activated inwardly rectifying potassium channel 4 and loss of the $\mathrm{K}_{\mathrm{ir}} 3.4$ gene strongly reduces cholinergic regulation of pacemaker activity in SAN cells and delays recovery of heart rate after stress, physical exercise or pharmacological $\beta$-adrenergic stimulation (76). Upregulation of $K c n j 5$ and $\mathrm{K}_{\mathrm{ir}} 3.4$ protein might partly underlie the slow heart rate in STZ rat heart (21-23). Kcnn2 encodes the small calcium-activated potassium channel member SK2. SK 2 mRNA has been detected in a variety of organs including heart and within the heart expression of SK channels are more abundant in the atria and pacemaking tissues compared with 
the ventricles $(77,78)$. Calcium-activated potassium channels are present in a variety of cells and serve to integrate changes in intracellular $\mathrm{Ca}^{2+}$ with changes in $\mathrm{K}^{+}$conductance and membrane potential (79). Overexpression of SK2 channels result in shortening of the spontaneous action potentials of AVN cells and an increase in firing frequency whilst genetic knockout of SK2 channels result in the delay in atrial myocyte repolarization and atrial arrhythmias $(80,81)$. Recent studies have demonstrated down-regulation of SK2 and prolonged action potentials in STZ-induced diabetic atria (82).

$N p p b$ and BNP protein were upregulated in AVN from STZ rat heart. Upregulation of $N p p a$ and $N p p b$ have recently been reported in the SAN from STZ-induced diabetic rat (35). The natriuretic peptides are a family of related peptides that include atrial natriuretic peptide (ANP) and B-type natriuretic peptide (BNP) that are secreted from the cardiac atria and ventricles (83). ANP and BNP decrease blood pressure and cardiac hypertrophy and BNP acts locally to reduce ventricular fibrosis and they are both involved in the pathogenic mechanisms leading to major cardiovascular diseases, including heart failure, coronary heart diseases, hypertension and left ventricular hypertrophy (83-85). Previous studies have demonstrated increases in ANP and BNP in blood plasma and atrial tissues and varying effects of ANP and BNP on the amplitude and kinetics of shortening and intracellular $\mathrm{Ca}^{2+}$ in ventricular myocytes from STZ-induced diabetic rat $(86,87)$. BNP has been shown to increase heart rate and electrical conduction velocity in isolated hearts and in the SAN and also increase spontaneous action potential frequency in isolated SAN myocytes (88). Upregulation of Nppb and BNP protein in the AVN may be associated with mechanisms that compensate for the low heart rate seen in the STZ-induced diabetic heart or alternatively be a consequence of the hypertrophy $(21-23,86,87)$.

The SAN and AVN contribute to the generation and orderly propagation of electrical signals in the heart and it is interesting that the expression of genes that encode a variety of proteins involved in cardiac electrical transmission are similarly altered in the SAN and AVN of STZ-induced diabetic rat (35). This study has demonstrated differences in the profile of mRNA encoding a variety of proteins that are associated with the generation, conduction and regulation of electrical signals in the AVN of STZ-induced diabetic rat heart. Data from this study will provide a basis for a substantial range of future studies to investigate whether changes in mRNA translate into changes in electrophysiological function.

\section{Acknowledgements}

The present study was supported by a grant from the UAE University.

\section{References}

1. Julien J: Cardiac complications in non-insulin-dependent diabetes mellitus. J Diabetes Complications 11: 123-130, 1997.

2. Malmberg K, Yusuf S, Gerstein HC, Brown J, Zhao F, Hunt D, Piegas L, Calvin J, Keltai M and Budaj A: Impact of diabetes on long-term prognosis in patients with unstable angina and non-Q-wave myocardial infarction: Results of the OASIS (Organization to Assess Strategies for Ischemic Syndromes) Registry. Circulation 102: 1014-1019, 2000
3. Piccini JP, Klein L, Gheorghiade $M$ and Bonow RO: New insights into diastolic heart failure: Role of diabetes mellitus. Am J Med 116 (Suppl 5A): S64-S75, 2004.

4. Poornima IG, Parikh P and Shannon RP: Diabetic cardiomyopathy: The search for a unifying hypothesis. Circ Res 98: 596-605, 2006.

5. Bouchard RA and Bose D: Influence of experimental diabetes on sarcoplasmic reticulum function in rat ventricular muscle. Am J Physiol 260: H341-H354, 1991.

6. Choi KM, Zhong Y, Hoit BD, Grupp IL, Hahn H, Dilly KW, Guatimosim S, Lederer WJ and Matlib MA: Defective intracellular $\mathrm{Ca}(2+)$ signaling contributes to cardiomyopathy in Type 1 diabetic rats. Am J Physiol Heart Circ Physiol 283: H1398-H1408, 2002.

7. Bracken N, Howarth FC and Singh J: Effects of streptozotocin-induced diabetes on contraction and calcium transport in rat ventricular cardiomyocytes. Ann N Y Acad Sci 1084: 208-222, 2006.

8. Kumar S and Sitasawad SL: Azelnidipine prevents cardiac dysfunction in streptozotocin-diabetic rats by reducing intracellular calcium accumulation, oxidative stress and apoptosis. Cardiovasc Diabetol 10: 97, 2011.

9. Shao CH, Wehrens XH, Wyatt TA, Parbhu S, Rozanski GJ, Patel KP and Bidasee KR: Exercise training during diabetes attenuates cardiac ryanodine receptor dysregulation. J Appl Physiol (1985) 106: 1280-1292, 2009.

10. Zhong Y, Ahmed S, Grupp IL and Matlib MA: Altered SR protein expression associated with contractile dysfunction in diabetic rat hearts. Am J Physiol 281: H1137-H1147, 2001.

11. Okatan EN, Tuncay E and Turan B: Cardioprotective effect of selenium via modulation of cardiac ryanodine receptor calcium release channels in diabetic rat cardiomyocytes through thioredoxin system. J Nutr Biochem 24: 2110-2118, 2013.

12. Shao CH, Rozanski GJ, Patel KP and Bidasee KR: Dyssynchronous (non-uniform) $\mathrm{Ca}^{2+}$ release in myocytes from streptozotocin-induced diabetic rats. J Mol Cell Cardiol 42: 234-246, 2007.

13. Ganguly PK, Pierce GN, Dhalla KS and Dhalla NS: Defective sarcoplasmic reticular calcium transport in diabetic cardiomyopathy. Am J Physiol 244: E528-E535, 1983.

14. Schaffer SW, Ballard-Croft C,Boerth S and Allo SN: Mechanisms underlying depressed $\mathrm{Na}^{+} / \mathrm{Ca}^{2+}$ exchanger activity in the diabetic heart. Cardiovasc Res 34: 129-136, 1997.

15. Yaras N, Ugur M, Ozdemir S, Gurdal H, Purali N, Lacampagne A, Vassort $\mathrm{G}$ and Turan B: Effects of diabetes on ryanodine receptor Ca release channel $(\mathrm{RyR} 2)$ and $\mathrm{Ca}^{2+}$ homeostasis in rat heart. Diabetes 54: 3082-3088, 2005.

16. Casis O and Echevarria E: Diabetic cardiomyopathy: Electromechanical cellular alterations. Curr Vasc Pharmacol 2: 237-248, 2004.

17. Movahed MR: Diabetes as a risk factor for cardiac conduction defects: A review. Diabetes Obes Metab 9: 276-281, 2007.

18. Fairfax AJ and Leatham A: Idiopathic heart block: Association with vitiligo, thyroid disease, pernicious anaemia, and diabetes mellitus. Br Med J 4: 322-324, 1975.

19. Movahed MR, Hashemzadeh M and Jamal MM: Increased prevalence of third-degree atrioventricular block in patients with type II diabetes mellitus. Chest 128: 2611-2614, 2005.

20. Kawai S, Fu L, Aziki K, Okada R and Katoh K: A degenerative lesion of the approach to the atrioventricular node producing second-degree and third-degree atrioventricular block. Pacing Clin Electrophysiol 15: 2263-2269, 1992.

21. Howarth FC, Jacobson M, Shafiullah M and Adeghate E: Effects of insulin treatment on heart rhythm, body temperature and physical activity in streptozotocin-induced diabetic rat. Clin Exp Pharmacol Physiol 33: 327-331, 2006.

22. Howarth FC, Jacobson M, Shafiullah M and Adeghate E: Long-term effects of streptozotocin-induced diabetes on the electrocardiogram, physical activity and body temperature in rats. Exp Physiol 90: 827-835, 2005.

23. Howarth FC, Al Sharhan R, Al Hammadi A and Qureshi MA: Effects of streptozotocin-induced diabetes on action potentials in the sinoatrial node compared with other regions of the rat heart. Mol Cell Biochem 300: 39-46, 2007.

24. Nygren A, Olson ML, Chen KY, Emmett T, Kargacin G and Shimoni Y: Propagation of the cardiac impulse in the diabetic rat heart: Reduced conduction reserve. J Physiol 580: 543-560, 2007.

25. Chattou S, Diacono J and Feuvray D: Decrease in sodium-calcium exchange and calcium currents in diabetic rat ventricular myocytes. Acta Physiol Scand 166: 137-144, 1999. 
26. Wang DW, Kiyosue T, Shigematsu S and Arita M: Abnormalities of $\mathrm{K}^{+}$and $\mathrm{Ca}^{2+}$ currents in ventricular myocytes from rats with chronic diabetes. Am J Physiol 269: H1288-H1296, 1995.

27. Lu Z, Jiang YP, Xu XH, Ballou LM, Cohen IS and Lin RZ: Decreased L-type $\mathrm{Ca}^{2+}$ current in cardiac myocytes of type 1 diabetic Akita mice due to reduced phosphatidylinositol 3-kinase signaling. Diabetes 56: 2780-2789, 2007.

28. Jourdon P and Feuvray D: Calcium and potassium currents in ventricular myocytes isolated from diabetic rats. J Physiol 470: 411-429, 1993.

29. Shimoni Y, Firek L, Severson D and Giles W: Short-term diabetes alters $\mathrm{K}^{+}$currents in rat ventricular myocytes. Circ Res 74: 620-628, 1994.

30. Zhang Y, Xiao J, Wang H, Luo X, Wang J, Villeneuve LR, Zhang H, Bai Y, Yang B and Wang Z: Restoring depressed HERG $\mathrm{K}^{+}$channel function as a mechanism for insulin treatment of abnormal QT prolongation and associated arrhythmias in diabetic rabbits. Am J Physiol 291: H1446-H1455, 2006.

31. Lengyel C, Virág L, Kovács PP, Kristóf A, Pacher P, Kocsis E, Koltay ZM, Nánási PP, Tóth M, Kecskeméti V, et al: Role of slow delayed rectifier $\mathrm{K}+$-current in QT prolongation in the alloxan-induced diabetic rabbit heart. Acta Physiol (Oxf) 192: 359-368, 2008

32. Yuill KH, Tosh D and Hancox JC: Streptozotocin-induced diabetes modulates action potentials and ion channel currents from the rat atrioventricular node. Exp Physiol 95: 508-517, 2010

33. Yuill KH, Al Kury LT and Howarth FC: Characterization of L-type calcium channel activity in atrioventricular nodal myocytes from rats with streptozotocin-induced diabetes mellitus. Physiol Rep 3: pii: e12632, 2015

34. Howarth FC, Nowotny N, Zilahi E, El Haj MA and Lei M: Altered expression of gap junction connexin proteins may partly underlie heart rhythm disturbances in the streptozotocin-induced diabetic rat heart. Mol Cell Biochem 305: 145-151, 2007.

35. Ferdous Z, Qureshi MA, Jayaprakash P, Parekh K, John A, Oz M, Raza H, Dobrzynski H, Adrian TE and Howarth FC: Different profile of mRNA expression in sinoatrial node from streptozotocin-induced diabetic rat. PLoS One 11: e0153934, 2016.

36. Yoo S, Dobrzynski H, Fedorov VV, Xu SZ, Yamanushi TT, Jones SA, Yamamoto M, Nikolski VP, Efimov IR and Boyett MR: Localization of $\mathrm{Na}^{+}$channel isoforms at the atrioventricular junction and atrioventricular node in the rat. Circulation 114: 1360-1371, 2006.

37. Yamamoto M, Dobrzynski H, Tellez J, Niwa R, Billeter R, Honjo H, Kodama I and Boyett MR: Extended atrial conduction system characterised by the expression of the $\mathrm{HCN} 4$ channel and connexin45. Cardiovasc Res 72: 271-281, 2006.

38. Yanni J, Boyett MR, Anderson RH and Dobrzynski H: The extent of the specialized atrioventricular ring tissues. Heart Rhythm 6 : 672-680, 2009

39. Souza AI, Felkin LE, McCormack AM, Holder A, Barton PJ Banner NR and Rose ML: Sequential expression of three known protective genes in cardiac biopsies after transplantation. Transplantation 79: 584-590, 2005.

40. Siu PM, Bryner RW, Murlasits Z and Alway SE: Response of XIAP, ARC, and FLIP apoptotic suppressors to 8 wk of treadmill running in rat heart and skeletal muscle. J Appl Physiol (1985) 99: 204-209, 2005

41. Khananshvili D: The SLC8 gene family of sodium-calcium exchangers (NCX)-structure, function, and regulation in health and disease. Mol Aspects Med 34: 220-235, 2013.

42. Sheikh AQ, Hurley JR, Huang W, Taghian T, Kogan A, Cho H, Wang Y and Narmoneva DA: Diabetes alters intracellular calcium transients in cardiac endothelial cells. PLoS One 7: e36840, 2012.

43. Hattori Y, Matsuda N, Kimura J, Ishitani T, Tamada A, Gando S, Kemmotsu O and Kanno M: Diminished function and expression of the cardiac $\mathrm{Na}^{+}-\mathrm{Ca}^{2+}$ exchanger in diabetic rats: Implication in $\mathrm{Ca}^{2+}$ overload. J Physiol 527 Pt 1: 85-94, 2000

44. Cheng H, Smith GL, Hancox JC and Orchard CH: Inhibition of spontaneous activity of rabbit atrioventricular node cells by KB-R7943 and inhibitors of sarcoplasmic reticulum $\mathrm{Ca}(2+)$ ATPase. Cell Calcium 49: 56-65, 2011.

45. Convery MK and Hancox JC: $\mathrm{Na}^{+}-\mathrm{Ca}^{2+}$ exchange current from rabbit isolated atrioventricular nodal and ventricular myocytes compared using action potential and ramp waveforms. Acta Physiol Scand 168: 393-401, 2000.

46. Hancox JC, Levi AJ and Brooksby P: Intracellular calcium transients recorded with Fura-2 in spontaneously active myocytes isolated from the atrioventricular node of the rabbit heart. Proc Biol Sci 255: 99-105, 1994.
47. Rowell J, Koitabashi N and Kass DA: TRP-ing up heart and vessels: Canonical transient receptor potential channels and cardiovascular disease. J Cardiovasc Transl Res 3: 516-524, 2010

48. Huang $\mathrm{H}$, Wang $\mathrm{W}$, Liu $\mathrm{P}$, Jiang $\mathrm{Y}$, Zhao $\mathrm{Y}$, Wei $\mathrm{H}$ and Niu W: TRPC1 expression and distribution in rat hearts. Eur J Histochem 53: e26, 2009.

49. Watanabe H, Murakami M, Ohba T, Ono K and Ito $\mathrm{H}$ : The pathological role of transient receptor potential channels in heart disease. Circ J 73: 419-427, 2009.

50. Ward ML, Williams IA, Chu Y, Cooper PJ, Ju YK and Allen DG Stretch-activated channels in the heart: Contributions to length-dependence and to cardiomyopathy. Prog Biophys Mol Biol 97: 232-249, 2008.

51. Ohba T, Watanabe H, Murakami M, Takahashi Y, Iino K, Kuromitsu S, Mori Y, Ono K, Ijijima T and Ito H: Upregulation of TRPC1 in the development of cardiac hypertrophy. J Mol Cell Cardiol 42: 498-507, 2007.

52. Ju YK and Allen DG: Store-operated $\mathrm{Ca}^{2+}$ entry and TRPC expression; possible roles in cardiac pacemaker tissue. Heart Lung Circ 16: 349-355, 2007.

53. Muthaian R, Pakirisamy RM, Parasuraman S and Raveendran R Hypertension influences the exponential progression of inflammation and oxidative stress in streptozotocin-induced diabetic kidney. J Pharmacol Pharmacother 7: 159-164, 2016

54. Choisy SC, Cheng H, Orchard CH, James AF and Hancox JC: Electrophysiological properties of myocytes isolated from the mouse atrioventricular node: L-type ICa, IKr, If and Na-Ca exchange. Physiol Rep 3: pii: e12633, 2015.

55. Kim D, Shinohara T, Joung B, Maruyama M, Choi EK, On YK, Han S, Fishbein MC, Lin SF and Chen PS: Calcium dynamics and the mechanisms of atrioventricular junctional rhythm. J Am Coll Cardiol 56: 805-812, 2010.

56. Ridley JM, Cheng H, Harrison OJ, Jones SK, Smith GL, Hancox JC and Orchard CH: Spontaneous frequency of rabbit atrioventricular node myocytes depends on SR function. Cell Calcium 44: 580-591, 2008

57. Yaras N, Bilginoglu A, Vassort G and Turan B: Restoration of diabetes-induced abnormal local $\mathrm{Ca}^{2+}$ release in cardiomyocytes by angiotensin II receptor blockade. Am J Physiol 292: H912-H920, 2007.

58. Le Douairon LS, Gratas-Delamarche A, Malardé L, Zguira S, Vincent S, Lemoine MS, Carré F and Rannou Bekono F: Combined insulin treatment and intense exercise training improved basal cardiac function and $\mathrm{Ca}(2+)$-cycling proteins expression in type 1 diabetic rats. Appl Physiol Nutr Metab 37: 53-62, 2012.

59. Wang M, Zhang WB, Zhu JH, Fu GS and Zhou BQ: Breviscapine ameliorates cardiac dysfunction and regulates the myocardial $\mathrm{Ca}(2+)$-cycling proteins in streptozotocin-induced diabetic rats. Acta Diabetol 47 (Suppl 1): S209-S218, 2010.

60. Ligeti L, Szenczi O, Prestia CM, Szabó C, Horváth K, Marcsek ZL, van Stiphout RG, van Riel Na, Op den Buijs J, Van der Vusse GJ and Ivanics T: Altered calcium handling is an early sign of streptozotocin-induced diabetic cardiomyopathy. Int J Mol Med 17: 1035-1043, 2006.

61. Bidasee KR, Nallani K, Henry B, Dincer UD and Besch HR Jr: Chronic diabetes alters function and expression of ryanodine receptor calcium-release channels in rat hearts. Mol Cell Biochem 249: 113-123, 2003.

62. Stolting G, de Oliveira RC, Guzman RE, Miranda-Laferte E, Conrad R, Jordan N, Schmidt S, Hendriks J, Gensch T and Hidalgo P: Direct interaction of $\mathrm{CaV} \beta$ with actin up-regulates L-type calcium currents in HL-1 cardiomyocytes. J Biol Chem 290: 4561-4572, 2015.

63. Soldatov NM: CACNB2: An emerging pharmacological target for hypertension, heart failure, arrhythmia and mental disorders. Curr Mol Pharmacol 8: 32-42, 2015.

64. Valdivia CR, Medeiros-Domingo A, Ye B, Shen WK, Algiers TJ, Ackerman MJ and Makielski JC: Loss-of-function mutation of the SCN3B-encoded sodium channel \{beta\} 3 subunit associated with a case of idiopathic ventricular fibrillation. Cardiovasc Res 86: 392-400, 2010.

65. Wang P, Yang Q, Wu X, Yang Y, Shi L, Wang C, Wu G, Xia Y, Yang B, Zhang R, et al: Functional dominant-negative mutation of sodium channel subunit gene SCN3B associated with atrial fibrillation in a Chinese GeneID population. Biochem Biophys Res Commun 398: 98-104, 2010.

66. Hakim P, Gurung IS, Pedersen TH, Thresher R, Brice N Lawrence J, Grace AA and Huang CL: Scn3b knockout mice exhibit abnormal ventricular electrophysiological properties. Prog Biophys Mol Biol 98: 251-266, 2008. 
67. Bissay V, Van Malderen SC, Keymolen K, Lissens W, Peeters U, Daneels D, Jansen AC, Pappaert G, Brugada P, De Keyser J and Van Dooren S: SCN4A variants and Brugada syndrome: Phenotypic and genotypic overlap between cardiac and skeletal muscle sodium channelopathies. Eur J Hum Genet 24 400-407, 2016.

68. Péréon Y, Lande G, Demolombe S, Nguyen The Tich S, Sternberg D, Le Marec H and David A: Paramyotonia congenita with an SCN4A mutation affecting cardiac repolarization. Neurology 60: 340-342, 2003.

69. Kassiri Z, Hajjar R and Backx PH: Molecular components of transient outward potassium current in cultured neonatal rat ventricular myocytes. J Mol Med (Berl) 80: 351-358, 2002.

70. Mitcheson JS and Hancox JC: Characteristics of a transient outward current (sensitive to 4-aminopyridine) in $\mathrm{Ca}^{2+}$-tolerant myocytes isolated from the rabbit atrioventricular node. Pflügers Arch 438: 68-78, 1999.

71. Marger L, Mesirca P, Alig J, Torrente A, Dubel S, Engeland B, Kanani S, Fontanaud P, Striessnig J, Shin HS, et al: Pacemaker activity and ionic currents in mouse atrioventricular node cells. Channels (Austin) 5: 241-250, 2011.

72. Howarth FC, Levi AJ and Hancox JC: Characteristics of the delayed rectifier $\mathrm{K}$ current compared in myocytes isolated from the atrioventricular node and ventricle of the rabbit heart. Pflugers Arch 431: 713-722, 1996.

73. Sato N, Tanaka H, Habuchi Y and Giles WR: Electrophysiological effects of ibutilide on the delayed rectifier $\mathrm{K}(+)$ current in rabbit sinoatrial and atrioventricular node cells. Eur J Pharmacol 404: 281-288, 2000

74. Hancox JC and Mitcheson JS: Ion channel and exchange currents in single myocytes isolated from the rabbit atrioventricular node. Can J Cardiol 13: 1175-1182, 1997.

75. Mitcheson JS and Hancox JC: An investigation of the role played by the E-4031-sensitive (rapid delayed rectifier) potassium current in isolated rabbit atrioventricular nodal and ventricular myocytes. Pflugers Arch 438: 843-850, 1999.

76. Mesirca P, Marger L, Toyoda F, Rizzetto R, Audoubert M, Dubel S, Torrente AG, Difrancesco ML, Muller JC, Leoni AL, et al: The G-protein-gated $\mathrm{K}^{+}$channel, IKACh, is required for regulation of pacemaker activity and recovery of resting heart rate after sympathetic stimulation. J Gen Physiol 142: 113-126, 2013.

77. Tuteja D, Rafizadeh S, Timofeyev V, Wang S, Zhang Z, Li N, Mateo RK, Singapuri A, Young JN, Knowlton AA and Chiamvimonvat $\mathrm{N}$ : Cardiac small conductance $\mathrm{Ca}^{2+}$-activated $\mathrm{K}^{+}$channel subunits form heteromultimers via the coiled-coil domains in the $\mathrm{C}$ termini of the channels. Circ Res 107: 851-859, 2010.

78. Chen MX, Gorman SA, Benson B, Singh K, Hieble JP, Michel MC, Tate SN and Trezise DJ: Small and intermediate conductance $\mathrm{Ca}(2+)$-activated $\mathrm{K}^{+}$channels confer distinctive patterns of distribution in human tissues and differential cellular localisation in the colon and corpus cavernosum. Naunyn Schmiedebergs Arch Pharmacol 369: 602-615, 2004.
79. Lu L, Zhang Q, Timofeyev V, Zhang Z, Young JN, Shin HS, Knowlton AA and Chiamvimonvat N: Molecular coupling of a $\mathrm{Ca}^{2+}$-activated $\mathrm{K}^{+}$channel to $\mathrm{L}$-type $\mathrm{Ca}^{2+}$ channels via alpha-actinin2. Circ Res 100: 112-120, 2007.

80. Zhang Q, Timofeyev V, Lu L, Li N, Singapuri A, Long MK, Bond CT, Adelman JP and Chiamvimonvat N: Functional roles of a $\mathrm{Ca}^{2+}$-activated $\mathrm{K}^{+}$channel in atrioventricular nodes. Circ Res 102: 465-471, 2008

81. Li N, Timofeyev V, Tuteja D, Xu D, Lu L, Zhang Q, Zhang Z, Singapuri A, Albert TR, Rajagopal AV, et al: Ablation of a $\mathrm{Ca}^{2+}$-activated $\mathrm{K}^{+}$channel (SK2 channel) results in action potential prolongation in atrial myocytes and atrial fibrillation. J Physiol 587: 1087-1100, 2009.

82. Yi F, Ling TY, Lu T, Wang XL, Li J, Claycomb WC, Shen WK and Lee HC: Down-regulation of the small conductance calcium-activated potassium channels in diabetic mouse atria. J Biol Chem 290: 7016-7026, 2015.

83. Potter LR, Yoder AR, Flora DR, Antos LK and Dickey DM: Natriuretic peptides: Their structures, receptors, physiologic functions and therapeutic applications. Handb Exp Pharmacol: 341-366, 2009

84. Volpe M, Rubattu S and Burnett J Jr: Natriuretic peptides in cardiovascular diseases: Current use and perspectives. Eur Heart J 35: 419-425, 2014.

85. McGrath MF, de Bold ML and de Bold AJ: The endocrine function of the heart. Trends Endocrinol Metab 16: 469-477, 2005.

86. Howarth FC, Al Shamsi N, Al Qaydi M, Al Mazrouei M, Qureshi A, Chandranath SI, Kazzam E and Adem A: Effects of brain natriuretic peptide on contraction and intracellular $\mathrm{Ca}^{2+}$ in ventricular myocytes from the streptozotocin-induced diabetic rat. Ann N Y Acad Sci 1084: 155-165, 2006.

87. Howarth FC, Adem A, Adeghate EA, Al Ali NA, Al Bastaki AM, Sorour FR, Hammoudi RO, Ghaleb NA, Chandler NJ and Dobrzynski H: Distribution of atrial natriuretic peptide and its effects on contraction and intracellular calcium in ventricular myocytes from streptozotocin-induced diabetic rat. Peptides 26 : 691-700, 2005.

88. Springer J, Azer J, Hua R, Robbins C, Adamczyk A, McBoyle S, Bissell MB and Rose RA: The natriuretic peptides BNP and CNP increase heart rate and electrical conduction by stimulating ionic currents in the sinoatrial node and atrial myocardium following activation of guanylyl cyclase-linked natriuretic peptide receptors. J Mol Cell Cardiol 52: 1122-1134, 2012. 